\title{
プローブ反応時間からみた自転車エルゴメータの 回転数に関する研究
}

\section{Relationship between Probe Reaction Time and Bicycle Ergometer RPM}

\section{劉 恵林1) 霍 明2) 丸山 仁司2)}

HuILIN LIU, MS, RPT ${ }^{1)}$, Ming HUO, MS, RPT ${ }^{2)}$, HITOSHI MARUYAMA, PhD, RPT ${ }^{2)}$

1) China Rehabilitation Research Center: 10 North Road, Fengtai District, Beijing, China. Tel +86 10-6756-3322

2) Department of Physical Therapy, Faculty of Heath Science, International University of Health and Welfare

Rigakuryoho Kagaku 21(1): 13-16, 2006. Submitted May 9, 2005. Accepted Nov. 17, 2005.

ABSTRACT: We measured the probe reaction time, which is an index of attentional demand, of 19 healthy people on a bicycle ergometer with changes of load and pedal revolutions, and determined the optimum RPM. The probe reaction time was measured at loads of 40,60, 80, 100, 120 watts at pedal revolutions of 20,40, 60, 80, 100 rpm, respectively. As a result of analysis of variance with pedal revolution as a factor, a significant effect was found. Furthermore, a post-hoc test (Tukey-Kramer test) showed significant differences between each of the pedal revolutions at 80, 100, 120 watts, and indicated the minimum probe reaction time at $60 \mathrm{rpm}$. These results suggest the optimal RPM was $60 \mathrm{rpm}$. Key words: probe reaction time, bicycle ergometer, optimal RPM (revolutions per minute)

要旨: 健康成人19名を対象に, 注意需要の指標であるプローブ反応時間を測定し, 自転車エルゴメータ駆動時負荷強 度とペダル回転数の変化により, 至適ペダル回転数を求めた。方法では, 運動強度は40, 60, 80, 100, 120 wattsにそ れぞれペダル回転数 $20 ， 40 ， 60 ， 80,100 \mathrm{rpm} の$ 条件で, プローブ反応時間を測定した。それぞれの運動強度のプロー ブ反応時間は回転数を要因とした分散分析の結果, 有意な主効果がみられた。また, 各ペダル回転数間を多重比較検 定（Tukey-Kramer検定）した結果，80，100，120 wattsにおいて各ペダル回転数間で有意差を認め，プローブ反応時間 は60 rpm時が最小值を示した。したがって, 至適ペダル回転数は60 rpmであることが推察できた。 キーワード : プローブ反応時間, 自転車エルゴメータ, 至適ペダル回転数

1）中国リハビリテーション研究センター：中国北京豊台区角門北路10号（社100068）TEL +86 10-6756-3322

2) 国際医療福祉大学 保健学部理学療法学科

受付日 2005年5月9日＼cjkstart受理日２005年11月17日 


\section{I.はじめに}

自転車エルゴメータの研究は, 工学, 医学, スポーツ 競技などの様々な分野で行われている。特に臨床医学で は, 運動負荷試験，全身持久力の維持・改善，心肺機能 の強化, 下肢筋力増強効果, 関節可動域の改善などを目 的とし, 内部障害疾患や中枢神経疾患及び整形外科疾患 患者などの運動療法として処方されている。

運動負荷試験の場合では, 自転車エルゴメータはト

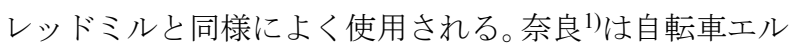
ゴメータの生理学的な負荷プロトコールについて, 運動 強度は50〜200 watts, ペダル回転数はトレーニングをし ていない人では $50 \sim 60 \mathrm{rpm}$ が適当であるとしている。し かし，よく鍛練された自転車競技選手では80 rpm以上で も可能である。老人や障害者がその速さを維持すること が困難な場合， $45 \mathrm{rpm}$ で行うことを推奨することもある。 また, 大川ら ${ }^{2)}$ は機械的効率の高いペダル回転数は60 rpm 前後と指摘した。至適速度はエネルギー必要量が最も少 なくなり作業の速さがあり, これを至適速度（Optimal Speed）という。至適速度をみるための指標に生理学的な ものと心理学的なものがあって, その心理学的な指標と して反応時間を用いるものがある。

心理学領域では, 環境からの情報を処理できる容量 (注 意を配分できる容量）には限界があると考えられてきた。 たとえば, ある運動課題をしている際に, 別の課題を行 わせる。運動課題が比較的単純であれば二次課題に向け られる注意は比較的多く配分することが可能であり，二 次課題に対する反応も比較的素早く遂行できることとな る(図1)。このように, ある運動課題施行中に二次課題 （単純反応時間）を挿入し，二次課題に対する反応時間が 相対的に短ければ，二次課題に対する注意の配分が多い と解釈し, 主課題は自動化していると判断をする。この ような研究手法をプローブ反応時間 (Probe Reaction Time，以下P-RTと略す）と呼んでいる。P-RTは主課題の 注意需要を敏感に識別する方法として推奨されてきてい る3)。P-RTは対象者が好みの速度で連続的運動する状態 で測定が可能なため, かなりの障害のある患者にも利用 できる利点がある。

こうしたP-RTを用いた注意需要の研究は歩行時につ いては行われていたが3), エルゴメータ駆動時については 行われていない。この研究の目的は, P-RTを用いて様々 な運動強度における至適ペダル回転数を求めることであ る。

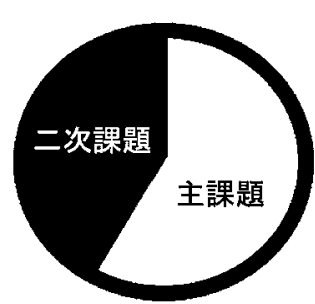

a)主課題の注意需要 が少ない場合

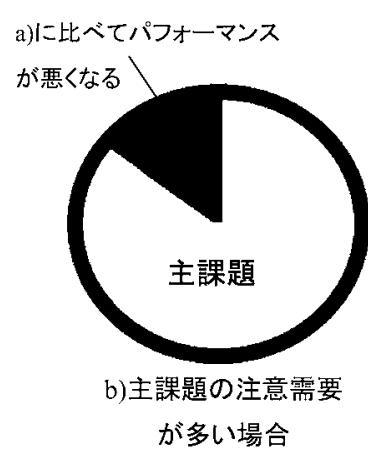

が多い場合 図1＼cjkstart容量モデルに基づく注意需要

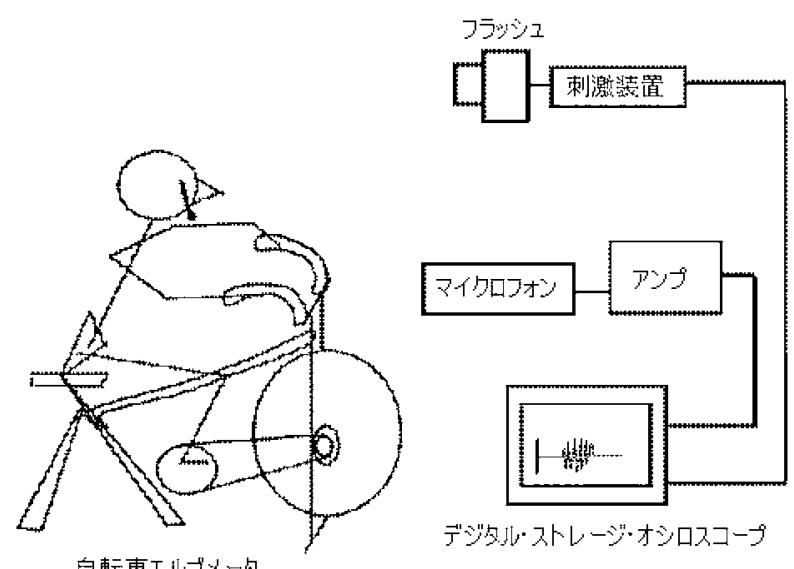

図2 プローブ反応時間（P-RT）測定装置概要

\section{II. 対象と方法}

対象者は健常成人男性 19 名（年齢: $22.8 \pm 4.5$ 歳, 身長 : $176 \pm 7.2 \mathrm{~cm}$, 体重 : $68.6 \pm 8.6 \mathrm{~kg}$ ) であった。全ての対象 者は自転車駆動経験者であった。全対象に本研究の目的, 方法, リスクなどを口頭で説明し, 研究参加の同意を確 認した。

課題は, 自転車エルゴメータ駆動時のP-RT課題であ る。主課題は自転車エルゴメータによる駆動運動, 二次 課題は光刺激に対寸る口頭での反応課題とした（図2）。

機器構成はデジタル・ストレージ・オシロスコープ DCS-7040（KENWOOD製, 以下オシロとする)を使用し, 光刺激装置は電気 ・光 - 音刺激装置SMP-3100（日本光電 富岡会社製）を使用した。また，自転車エルゴメータは エルゴメータ $232 \mathrm{CXL}$ (コンビ製) を使用した。サドルの 高さは有酸素的作業時に, 一番効率的であるとされる大

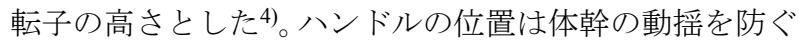


ため, 各運動強度における肩関節屈曲 $60^{\circ}$ になるように調 節した5)。

実験機械内の信号の流れでは, 測定開始前, 対象者に は1.5 m前方から発せられる光刺激（Duration, $0.1 \mathrm{sec）を}$ 感知したらできるだけ素早く口頭で “パァ”と発するよ う指示した。光刺激の2～3秒前に, 口頭で “ヨーイ”の 予告合図を入れた。対象者の発声音はヘッドホーンに取 り付けたマイクロフォンにより集音し, 光刺激装置の刺 激開始信号によるトリガーでオシロの挿引を開始し, 画 面上に波形を描出した。光刺激から発声音までの潜時の 測定は, オシロの画面上の画面を一回毎にストップし カーソルを移動して行った。

実際の実験の手続きでは，各運動強度は40，60，80， 100，120 wattsであり，ペダル回転数 $20 ， 40 ， 60,80,100$ rpmをランダムにして発声による反応時間の測定を行っ た。反応時間の測定は, 自転車エルゴメータ駆動開始 3 分 から3分の間に10回の光刺激をランダムに与えた。実験前 には，実験内容の説明を行い，課題に慣れるために数回 の練習を施行した。疲労を考慮し, ペダル回転数を変え る度に5〜10分間の休憩時間を入れた。また, 各対象者に おいて全ての測定を同じ日に実行し, 検者違いによる誤 差を避けるため, P-RTの測定, 記録は同一検者で行った (図3)。

統計分析では, P-RT測定值をコンピューターに入力, 解析ソフトStatviewを用いて, 対象者とペダル回転数をそ れぞれ要因とする2元配置分散分析を行い, さらに各ペダ ル回転数間に多重比較検定（Tukey-Kramer検定）を行っ た。

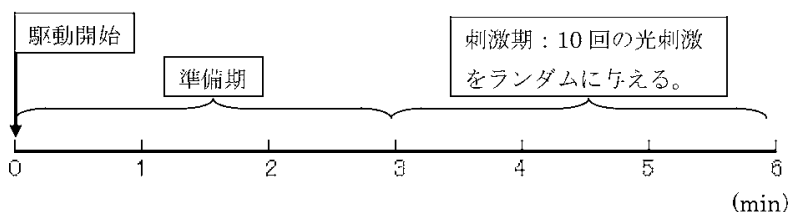

図3 プローブ反応時間（P-RT）測定の流れ

\section{III. 結 果}

各運動強度及び各ペダル回転数時のP-RTの平均值と 標準偏差を表1に示す。P-RTについて対象者とペダル回転 数をそれぞれ要因とする2元配置分散分析の結果, 各 40 , $60 ， 80 ， 100 ， 120$ watts時のペダル回転数について有意な 主効果を認めた $(\mathrm{F}(4,927)=18.355 \mathrm{p}<0.01, \mathrm{~F}(4,927)=9.232$ $\mathrm{p}<0.01, \mathrm{~F}(4,927)=32.451 \mathrm{p}<0.01, \mathrm{~F}(4,927)=24.500 \mathrm{p}<0.01$, $\mathrm{F}(4,927)=23.753 \mathrm{p}<0.01)$ 。各ペダル回転数間を多重比較検 定（Tukey-Kramer検定）した結果，80，100，120 wattsに おいて各ペダル回転数間で有意差を認め, P-RTは60 rpm 時が最小值を示した。被験者についても有意な主効果を 認めた $(\mathrm{F}(18,4)=42.809 \mathrm{p}<0.01, \mathrm{~F}(18,4)=52.613 \mathrm{p}<0.01$, $\mathrm{F}(18,4)=53.858 \mathrm{p}<0.01, \quad \mathrm{~F}(18,4)=51.457 \mathrm{p}<0.01, \quad \mathrm{~F}(18$, $4)=48.670 \mathrm{p}<0.01)$ 。

\section{IV. 考 察}

自転車エルゴメータ駆動中のヒトの注意需要がどのよ うになっているのかを知るため, それぞれの運動強度で P-RTとペダル回転数との関係について, 5 段階の運動強度 で検討した。いずれの運動強度においてもP-RTについて 対象者とペダル回転数をそれぞれ2要因とする分散分析 の結果では，ペダル回転数について有意な主効果を認め た。また，80，100，120 wattsにおいて，各ペダル回転数 におけるP-RTの変化は60 rpmの時に最小值を示した。

歩行については， $5 \mathrm{~km} / \mathrm{h}$ の歩行速度が健康人の自由歩 行速度であり, 最も効率がよい歩行速度とされている。 エネルギー面からみると, 単位距離当りのエネルギー消 費量は4.5〜 $5 \mathrm{~km} / \mathrm{h}$ 時が最も小さく, 歩行能率がよい6)。黒 澤7)は更に歩行時のPCI（physiological cost index）とP-RT の関係を求めた結果, P-RTの最小值を示した速度とPCI の最小值を示した速度が一致していることを報告した。 このことは効率のほぼ逆数である歩行能率という観点か らみると, PCIで評価した值とP-RTの最小值を示す值が 一致したことを意味し，P-RTがPCIと同様にエネルギー

表1 各運動強度, ペダル回転数におけるプローブ反応時間（P-RT）

$(\mathrm{msec})$

\begin{tabular}{|c|c|c|c|c|c|c|}
\hline & 40 watts & 60 watts & 80 watts & 100 watts & 120 watts & \\
\hline $20 \mathrm{rpm}$ & $249.8 \pm 21.6$ & $238.1 \pm 51.2$ & $243.2 \pm 44.9-$ & $242.8 \pm 43.2 \square$ & $244.6 \pm 42.6$ & \\
\hline $40 \mathrm{rpm}$ & $240.7 \pm 19.1$ & $228.6 \pm 36.5$ & $224.9 \pm 38.77_{*} *$ & $229.8 \pm 36.3\rceil_{*}$ & $228.6 \pm 37.0_{7 *}$ & $*$ \\
\hline $60 \mathrm{rpm}$ & $227.5 \pm 19.1$ & $223.6 \pm 37.8=$ & $214.0 \pm 30.2 \stackrel{\overrightarrow{7}}{7}$ & $217.8 \pm 31.3 \stackrel{\square}{7}$ & $218.6 \pm 31.6 \overline{\overline{7}}$ & \\
\hline $80 \mathrm{rpm}$ & $241.5 \pm 13.6$ & $225.7 \pm 35.3$ & $229.5 \pm 35.2\rfloor^{*} *$ & $229.2 \pm 32.0]^{*}$ & $228.7 \pm 35.7\rfloor^{*}$ & $*$ \\
\hline $100 \mathrm{rpm}$ & $260.9 \pm 27.9$ & $236.7 \pm 45.4$ & $234.2 \pm 34.5-$ & $237.5 \pm 40.7$ & $235.9 \pm 41.2$ & \\
\hline
\end{tabular}

平均值士標準偏差. $\mathrm{rpm}$ : ペダル回転数. $\mathrm{n}=19, * \mathrm{p}<0.05$ 
能率の指標として利用できることを示している。

更に，自由歩行時の至適歩行率は110歩/分であり，歩 行率を低下または増大させても能率は低下することも報 告されている6)。トレッドミル上の至適速度・歩行率の結 果と同様，P-RTからみた自転車エルゴメータでの能率の 検討も基礎的な研究として意義あるものである。トレッ ドミルと同様に至適ペダル回転数があることが明らかと なった。自転車では，一般的に50〜 60 rpmが推奨されて いるが1), これは歩行率110歩/分が自転車のペダル回転数 $55 \mathrm{rpm}$ に一致することから, 下肢運動には固有リズムが あり，60回転前後であることが推察できる。

リハビリテーション医学の領域では, 歩行機能に障害 を受けた身体障害者の歩行機能評価としてPCIが臨床上 簡便で有用であるが，P-RTはエネルギー能率の指標とし てPCIと同様に利用できることが明らかとなった7)。

今回の実験において, 注意需要の観点から自転車エル ゴメータ駆動時 80 watts以上の運動強度において $60 \mathrm{rpm} の$ 時にP-RTが最小值を示し, $60 \mathrm{rpm}$ の時に最も注意需要を 必要としないことがわかった。ペダル回転数60 rpmの時 に自転車エルゴメータ駆動動作は最も自動化されている
と考えられる。すなわち, ペダル回転数 $60 \mathrm{rpm}$ は至適ペ ダル回転数であることが推察できる。今後エネルギー消 費能率と合わせて検討が必要である。

本研究にあたり，御指導を頂いた丸山仁司教授，黒澤 和生先生に深く感謝申し上げます。

\section{引用文献}

1) 奈良 勲: 理学療法士のための運動処方マニュアル第 2 版. 文光堂, 東京, 2002, pp298-303.

2) 大川信夫 : 自転車エルゴメータ運動の機械的効率. 日大医 学, 1986, 45(2) : 155-162.

3) 黒澤和生 : 運動分析一反応時間を中心として一. 理学療法の ための運動生理, 1993，8(3)：135-140.

4) Nordeen-Snyder KS: The effect of bicycle seat height variation upon oxygen consumption and lower limb kinematics. Med Sci Sports Exerc, 1977, 9(2): 113-117.

5) 新井光男 : 自転車エルゴメータのサドルの高さの決定基準と パワー差の検討. 理学療法のための運動生理, 1986, 1(1) : 3-5.

6) 理学療法科学学会監修: ザ・歩行. 丸山仁司 (編), アイペッ ク, 東京, 2003, pp45-46.

7) 黒澤和生 : P-RTからみた移動能率に関寸る研究. 杏林医学, 1994, 25(4) : 527-536. 